\title{
IN VESTIGATIONS IN VESTSPITSBERGEN
}

\author{
By D. L. Dineley \\ (University College of the South-West, Exeter)
}

\begin{abstract}
Deep, partly snow-filled gullies cutting the sea cliffs of part of the Vestspitsbergen strandfat are noted. They do not appear to have been cut by streams, and it is suggested that a process of frost action and snowpatch erosion has been largely responsible for their formation.

A short note on glacial recession in part of Vestspitsbergen is added.

Zusammenfassunc. Es werden tiefe, teilweise mit Schnee gefüllte Rinnen erwähnt, die die Seefelsen eines Teiles der West Spitzbergen Strandfläche (,,Strandflat") einschneiden. Sie scheinen nicht durch Ströme eingeschnitten zu sein, und es wird angenommen, dass Frostangriff und Schneeflecken-Erosion hauptsächlich für die Bildung dieser Rinnen verantwortlich ist.

Ein kurzer Beitrag über den glazialen Rückgang in Teilen der West Spitzbergen ist beigefügt.
\end{abstract}

\section{GULLY EXCAVATION ON THE VESTSPITSBERGEN STRANDFLAT} THE presence of deep, partly snow-filled gullies on the Vestspitsbergen strandflat attracted the writer's attention in the summer of 195 r. (Fig. I, p. 38r.) There was little drainage entering these gullies, and little indication that any had done so in the past, yet the gullies frequently cut down in a most impressive way 12 to $15 \mathrm{~m}$. through the coastal cliffs of Hecla Hook (Lower Palaeozoic) slates, green schists and quartzites. Gully excavation to-day seems to be largely a process of nivation, and the location of the gullies does not appear to be influenced by faults or other zones of structural weakness, except perhaps joints. The gullies are, however, developed in the more fissile, steeply dipping strata. Except for this there is no discernible pattern to their grouping.

The strandflat on the western coast of Vestspitsbergen is very well developed; at Daudmannsøyra it reaches ten kilometres or so in width. Here the summer months are warmer and wetter than to the east and north. The glaciers are all in a state of decay, but many snow patches on the mountain sides and the strandflat persist throughout the entire summer. These snow patches conform to the types described by Lewis ${ }^{1}$ and by McCabe. ${ }^{2}$ There is remarkably little relief to the strandflat; it rises from sea cliffs varying from about $18 \mathrm{~m}$. in height to as much as $45 \mathrm{~m}$. or more at the foot of the mountains, and is largely covered by a mantle of raised beach shingle or locally derived gravel. In the area visited, to the south of Müllerneset in Forlandsundet, small streams, few of which warrant the term "river," cross the strandflat, but the cliffs are fissured in many places by gullies capable of carrying large volumes of water.

\section{The Gullies}

The gullies to which particular attention was paid are situated south of Müllerneset, but others were noted south of Farmhamna. They incise cliffs up to $12 \mathrm{~m}$. high, and occasionally higher. The gullies reach back some 45 to $55 \mathrm{~m}$. to emerge upon the surface of the strandflat, and are seldom more than $3 \mathrm{~m}$. wide. The long profile of the gullies is thus fairly steep. (Fig. 2, p. $38 \mathrm{r}$.) The walls of the gullies are extremely steep or vertical for the greater part of their length, although gentler slopes are found at the inland ends of some; the mouths generally open out abruptly at the shore. (Fig. 3, p. 38r.)

Several small streams may flow into the gullies, but throughout August-September these were the merest trickle. The amount of spring melt water that enters the gullies is considerably greater, but the superficial deposits nearby, being uncut by watercourses, show no evidence of any previous larger scale drainage converging upon the gullies. Seepage from the mantle into the gullies may, at times, be considerable, but not sufficient to produce any great excavation.

Common to almost every gully encountered is the presence of a snow patch occupying a large part of its lower reaches. The lowest parts of the gullies are virtually in continual shadow, and it is here that the snow patches are thickest. The patches persist even where receiving a certain amount of direct sunshine. Lewis noted that the chief factor in the preservation of snow patches seemed to be their bulk rather than continual shadow. In places the snow within the gullies was 
seen to reach a thickness of 4.5 to $5.4 \mathrm{~m}$., and to persist throughout the summer. A well-marked laminar structure is present in some of the snow patches, and the lowest layers are in a very compacted form. Dirt bands and gritty layers can be seen in some snow patches, where fine dirt can fall or be blown onto the snow. If this process takes place each year, some of the snow patches must be fifteen years old, many others much older.

From the foot of the snow patches flowed an incessant, though extremely small, stream of water. This trickle was arrested with the first night frosts of the autumn, becoming frozen during the night and returning during the daytime when temperature rose. Beneath the snow patch the rock surface and gravel were wet, the water appearing to flow down from the surface where it had been produced by snow melt or had seeped from the mantle. Thus in some gullies there was a clear channel, cut in the snow patch, down which water drained, but in the majority the water emerging at the lower end of the gully passed under the snow patch as a thin film or along minute channels. The loose, locally derived material lying at the bottom of the gullies was never of very great size, fragments larger than $5 \mathrm{~cm}$. appearing to be rare, and many of these were shattered and decomposing.

\section{The Excavation of the Gullies}

Active coastal erosion of the cliffs in which the gullies occur is taking place to-day, but the intense nivation experienced must have a very great effect in denudation as well.

In a general way the snow patches in the gullies are similar to the longitudinal snow patches described by Lewis. Under certain conditions stream erosion in the hollows in which the Iceland snow patches were found can be more rapid than nivation. Here the importance of melt water from above seeping beneath the snow patch was emphasized by Lewis.

The rapid examination of the gullies and their snow patches on the Vestspitsbergen strandflat suggests that with the emergence of the strandflat and the formation of coastal cliffs, small irregularities would develop in the cliff tops. Small drainage courses might persist, along which frost action would assist in the excavation in the extremely brittle, fissile rocks. The depressions so produced may become the sites of snow patches. Fluctuating spring and autumn temperatures soon bring about frost shattering, and the persistence of the snow patches enhances prolonged nivation, as described by Lewis and by McCabe. The gentle drainage entering the gullies to-day provides extra water, supplementing the melt water of the snow patch, to bear away the fine mud and comminuted particles which result beneath the snow patch. As the gullies deepen by this process of accelerated nivation, so the volume of the contained snow patch may increase and nivation be extended. The constant quick removal of the waste material tends also to induce the snow patch to deepen its hollow rather than widen it. As the gullies grow, stream abrasion may become more important, but the excavation of these features so far appears to have been largely controlled by a form of snow-patch erosion.

\section{REFERE N CES}

r. Lewis, W. V. Snow-patch erosion in Iceland. Geographical Fournal, Vol. 94, No. 2, I939, p. x 53-6r.

2. McCabe, L. H. Nivation and Corrie Erosion in West Spitsbergen. Geographical Fournal, Vol. 94, No. 6, 1939, p. 447-65.

\section{GLACIAL RECESSION IN PARTS OF VESTSPITSBERGEN}

IT is well known that the present form of the Vestspitsbergen glaciers indicates a relatively rapid and recent disintegration of a once fairly continuous ice cap. This disintegration is most obvious along the western coastal belt. In the Trygghamna-St. Jonsfjorden region only Osbornebreen, Charlesbreen, Bullbreen and Kjerulfbreen still calve into the sea (see sketch map, p. 382 ). The cliffs of Osbornebreen are now no longer continuous with those of Konowbreen, due to the $5-\mathrm{km}$. retreat of the last twenty years. Eidembreen has, in its retreat, been noted by several writers. 

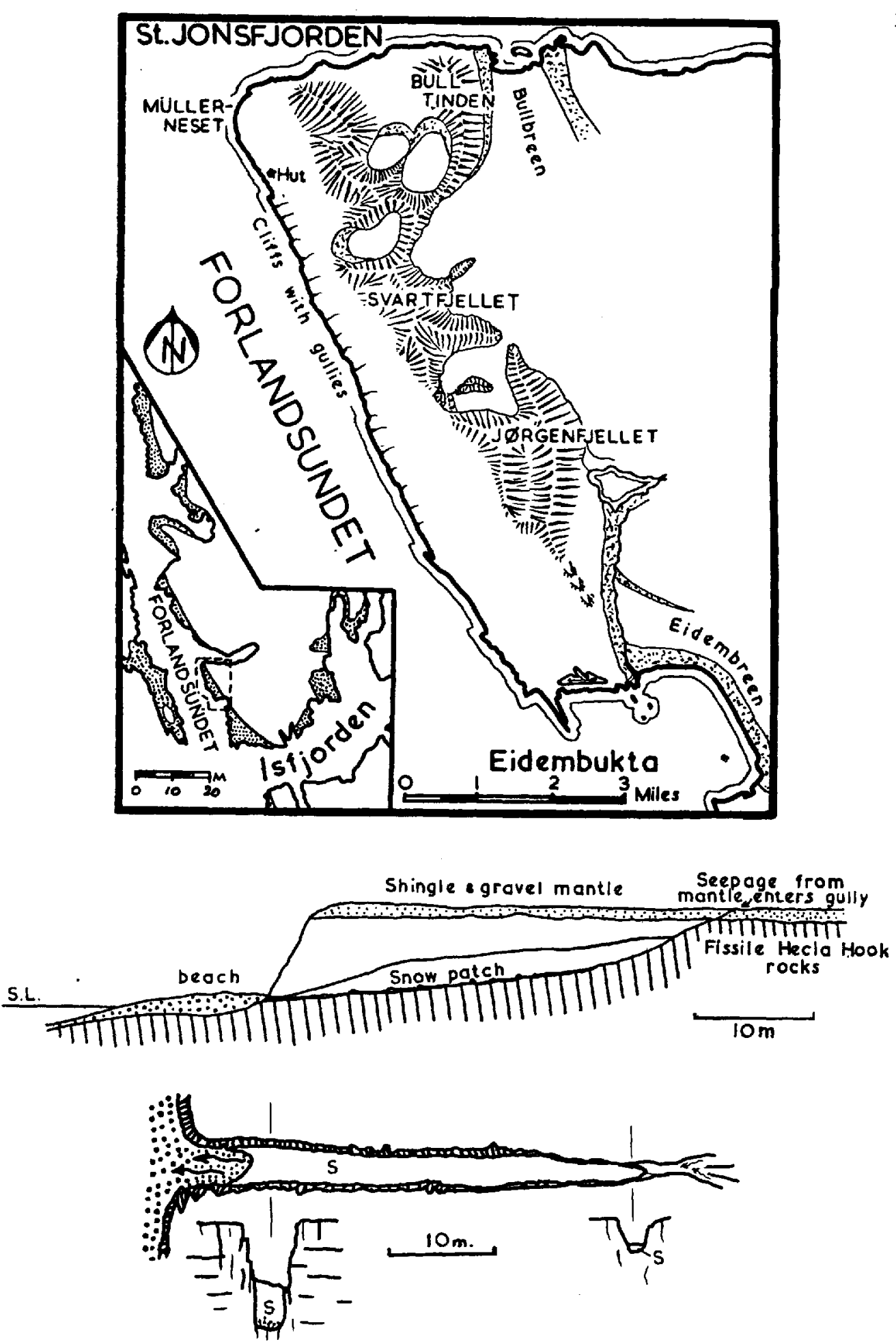

Fig. I (top). Sketch map of coastal region between St. Fonsfjorden and Eidembukta, Vestspitsbergen, showing area in which gullies were examined. Stippled area in inset map represents strandflat

Fig. 2 (centre). Diagrammatic section along a cliff gully containing a permanent snow-patch

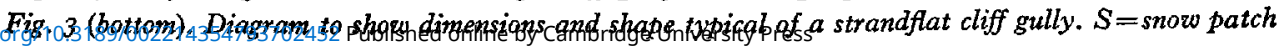




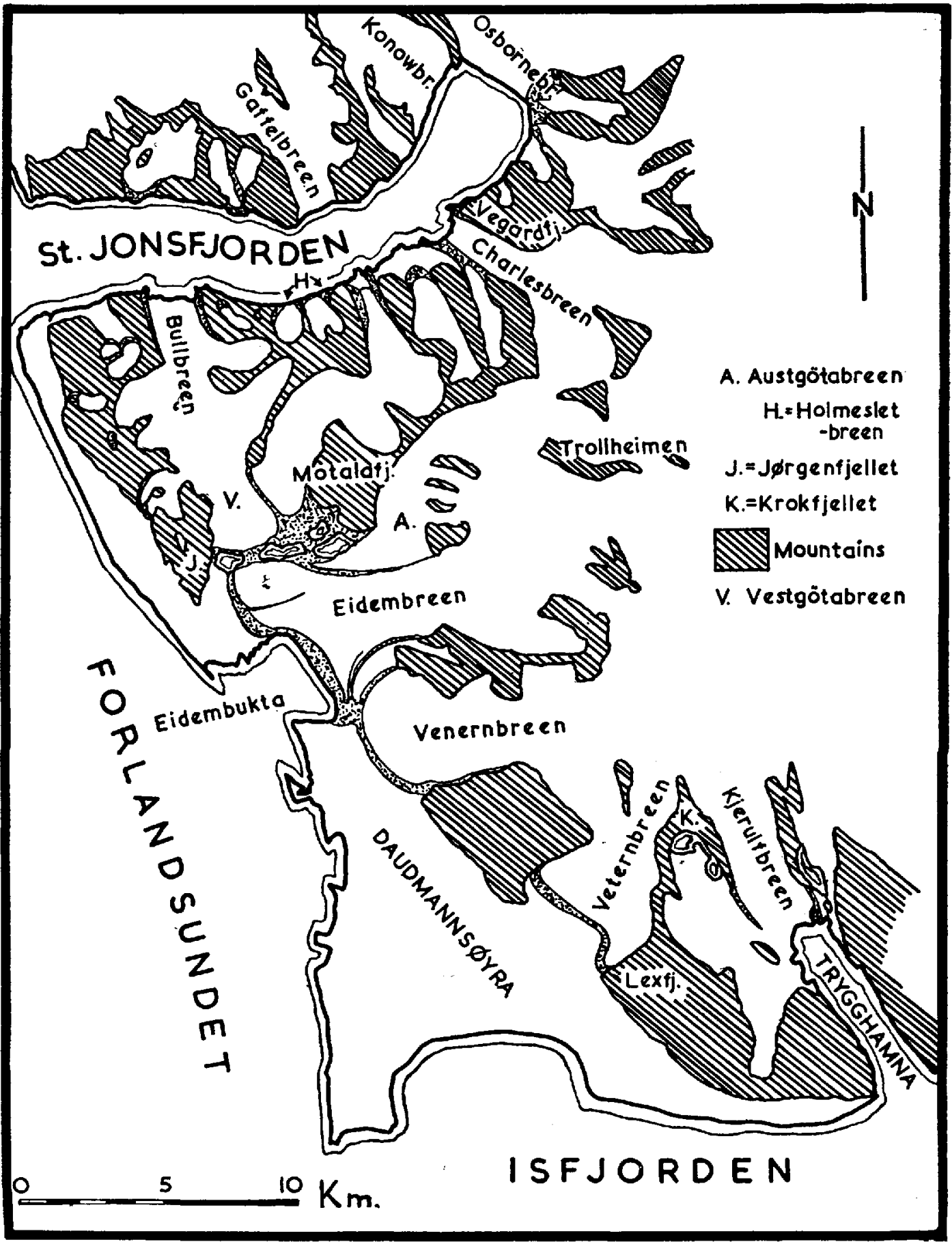

Fig. 4. Sketch-map of the St. Fonsfjorden-Trygghamna region of Vestspitsbergen 
In $1926{ }^{1}$ ice cliffs apparently stretched across the entire end of the glacier and it calved into the sea, as shown in Fig. 16 of the reference cited. The Norsk Polarinstitutt aerial photographs of 1936 show a bay-head bar developing, with ice cliffs persisting only at the southern end of the bay. To-day no cliffs remain, and the ice has now retreated some $80 \mathrm{~m}$. from its terminal moraine behind the bar.

The retreat of the ice front is accompanied by an overall thinning of the glaciers, due mainly to ablation, which amounts to about $\mathrm{I} \mathrm{m}$. per annum. The great ice-cored moraines of these glaciers are an indication of the extent to which this has gone on. Some of these moraines rise as much as $5^{\circ} \mathrm{m}$. above the ice snout, and several are accompanied by numerous dirt cones up to $7 \mathrm{~m}$. high.

An interesting aspect of glacial recession in Vestspitsbergen is that of relic pro-glacial features. On the northern flank of Vegardfjella, St. Jonsfjorden, a group of beach remnants of former glint lakes (glacier dammed lakes) is present between 30 and $47 \mathrm{~m}$. above sea level. The effect is of a group of three "parallel roads," and it is clear that a lake was confined between Vegardfjella and the adjoining glaciers Osbornebreen and Charlesbreen. With the retreat of Osbornebreen the water presumably escaped into the fjord.

Small glint lakes are present below Krokfjellet, their outflow being subglacial or englacial. Numerous old lake shorelines are present above these lakes, the highest being about $39 \mathrm{~m}$. above present lake level on the southern spur of Krokfjellet.

The glint lakes between Eidembreen and Vestgötabreen, below Motalafjella, appear to be growing in size, and, whereas only one lake has been shown on the published maps of this area, several lakes now exist. The outflow from these lakes in the summer of $195 \mathrm{I}$ no longer took place from their western ends and down the valley below Jørgenfjellet, but past their eastern end and down ice gorges cut in the snout of Eidembreen. The writer is indebted to Dr. A. K. Orvin of the Norsk Polarinstitutt for a pre-publication view of a map showing these lakes. This map differs in certain details from sketches made by the writer in $195 \mathbf{I}$, and it is hoped that a further field season will allow a careful survey of the lakes to be made, and their recent growth to be assessed. With continued glacial recession, this lake site may eventually witness the accumulation of a very large lake or group of lakes stretching almost from Jørgenfjellet to Motalafjella.

MS. received 6 fune $\mathrm{r} 953$

RE F E R E N C E

1. Hoel, A. The Norwegian Svalbard Expeditions 1906-26. Skrifter om Svalbard og Ishavet, Bd. X, Nr. I, 1929, 104 p.

\title{
AN EXCEPTIONAL GLACIER ADVANCE IN THE K A R A K OR A M - LA D A K H REGION
}

\author{
By Ardito Desio \\ (Director, Istituto Geologia Università, Milan)
}

DuRING my recent travel in the Western Karakoram, and by request of the Pakistan Government, I was able to see, and to make a preliminary study of, a very extraordinary glacier situated in the Stak Valley, which joins the right bank of the Indus River between Skardu and Gilgit.

I refer to the 12 kilometres long "Kutiàh Glacier," so called after the valley in which it had formed itself in a period of about three months. As far as my knowledge goes, no such rapid advance in historic times of a glacial front such as this has been recorded, and I regard it therefore as quite an exceptional phenomenon. 